\title{
PERMAINAN TRADISIONAL SEBAGAI MEDIA PENGEMBANGAN KEMAMPUAN SOSIAL ANAK
}

\author{
Rina Wijayanti ${ }^{1}$
}

\begin{abstract}
ABSTRAK
Periode emas pada masa anak-anak di awali ketika anak memasuki usia 0-5 tahun. Pada fase ini kemampuan anak berkembang dengan pesat sebagai dasar perkembangan tahap berikutnya. Dunia bermain adalah dunia anak. bermain sebagai media stimulasi bagi aspek perkembangan fisik, emosi, sosial, bahasa dan budaya. Permainan tradisional menyediakan kesempatan bagi anak untuk memunculkan potensi dan menstimulasi berkembangnya kemampuan anak. permainan tradisional memiliki karakteristik menggunakan fasilitas di lingkungan tanpa harus membeli, melibatkan banyak anak, dan permainannya memiliki aturan. Dengan karakter permainan tradisional bisa dijadikan media pengembangan kemampuan sosial anak. Dalam permainan tradisional anak akan mengembangkan kemampuan dalam kerja sama, mampu menyesuaikan diri, saling berinteraksi secara positif, mampu mengontrol diri, mampu mengembangkan sikap empati pada teman, memiliki kemampuan dalam menaati peraturan, serta mampu menghargai orang lain. Dengan banyak terlibat dalam permainan tradisional akan mengembangkan kemampuan anak dalam bersosialisasi.
\end{abstract}

Kata kunci : permainan tradisional, kemampuan sosial anak

\section{A. PENDAHULUAN}

Pendidikan anak usia dini merupakan pendidikan paling mendasar menempati posisi yang sangat strategis dalam pengembangan sumber daya manusia (direktorat PAUD: 2005) karena rentang usia kritis dan sekaligus strategis dalam proses pendidikan dapat mempengaruhi proses serta hasil pendidikan pada tahap selanjutnya. Periode ini juga merupakan periode kondusif untuk mengembangkan aspek kemampuan fisik motorik, emosi, sosial emosional, dan bahasa.

Bermain merupakan metode yang tidak bisa ditinggalkan pada anak usia dini, anak akan mendapatkan keceriaan dan berekspresi dengan bebas ketika bermain. Anak adalah "pembelajar alamiah" karena mereka akan belajar efektif bila kegiatan dilakukan dalam kondisi yang menyenangkan, tanpa paksaan.

Interaksi sosial mulai terjadi di lingkungan keluarga, terutama pada ayah, ibu, dan saudaranya. Seiring dengan perkembangan usianya anak semakin ingin berinteraksi dengan lingkungan yang lebih luas, seperti di sekolah maupun di masyarakat. Tidak ada masa yang lebih potensial untuk belajar daripada masa tahun-tahun awal kehidupannya.

Anak anak belajar melalui permainan untuk menambah pengalaman dengan bahan, benda dan teman sebaya atas dukungan orang dewasa. Dunia permainan anak berkembang sesuai dengan peradaban global. Pemilihan permainan yang sesuai dengan tujuan aspek pencapaian kecakapan hendaknya menjadi tujuan utama

1 Dosen Universitas Kanjuruhan Malang 
bagi guru maupun orang tua. Memfasilitasi anak dengan permainan harga mahal, mainan import bukan tolak ukur suatu mainan harus disediakan untuk anak. Permainan yang murah, yang dibuat dengan menggunakan bahan bekas, permainan warisan nenek moyang bisa menjadi media bagi bermain anak-anak dan mampu mengembangkan kemampuan sosial anak .

Permainan tradisional merupakan alternatif yang kaya akan nilai budaya dan bahkan hampir tanpa adanya pelestarian. Permainan tradisional yang ada mirip dengan olahraga yakni memiliki aturan main dan mampu memberikan kesenangan, relaksasi, kegembiraan dan tantangan. Guna memfasilitasi pengembangan kemampuan sosial anak memanfaatkan permainan tradisional sebagai modal budaya yang dimiliki Indonesia sebagai fasilitasnya. Mengembangkan kemampuan sosial anak bisa berlangsung di lingkungan sekolah, rumah dan di masyarakat. Menurut Tilaar (2002) dalam budaya global diperlukan pendidikan yang dapat mempersiapkan manusia-manusia beridentitas lokal dengan visi global untuk membangun dunia bersama.

Anak Indonesia memerlukan identitas bangsa yaitu kerja sama gotong royong yang dapat di berikan dan dihayati anak-anak melalui permainan tradisional. Dengan memiliki kemampuan sosial yang baik maka identitas kebersamaan dan kegotong-royongan dapat terwujud.

\section{B. PEMBAHASAN \\ 1. Hakikat Bermain}

Bermain bagi anak usia dini adalah belajar. Bermain yang dilakukan menimbulkan kesenangan serta kepuasan bagi anak. Bermain sebagai sarana pengembangan kemampuan sosial anak diharapkan mampu memberikan kesempatan untuk bereksplorasi, menemukan, mengekspresikan perasaan, berkreasi, dan belajar secara menyenangkan.

Di lingkungan yang masih terlihat keakraban antar anggota masyarakat, banyak permainan yang dilakukan oleh anak-anak secara beramai-ramai dengan teman-teman mereka di halaman atau di teras rumah. Mereka berkelompok, berlarian, atau duduk melingkar memainkan salah satu permainan dan tercipta keakraban. Permainan merupakan sebuah aktivitas rekreasi dengan tujuan bersenang-senang, mengisi waktu luang, atau berolahraga ringan. Permainan biasanya dilakukan sendiri atau bersama-sama.

Semiawan (2003) mengungkapkan beberapa nilai dan ciri penting dari bermain dalam kemajuan perkembangan kehidupan sehari-hari seorang anak. Nilai dan ciri penting tersebut antara lain adalah:

a. Bermain memiliki berbagai arti. Pada permulaan, setiap pengalaman bermain memiliki unsur resiko. Ada resiko bagi anak untuk belajar berjalan sendiri, atau naik sepeda sendiri atau berenang, ataupun meloncat. Betapapun sederhana permainannya, unsur resiko itu selalu ada.

b. Unsur lain adalah pengulangan. Dengan pengulangan, anak memperoleh kesempatan mengonsolidasikan keterampilannya yang harus diwujudkannya dalam berbagai permainan dengan berbagai nuansa yang berbeda. Sesudah pengulangan itu berlangsung, anak dapat meningkatkan keterampilannya yang 
lebih kompleks. Melalui berbagai permainan yang diulang, ia memperoleh kemampuan tambahan untuk melakukan aktivitas lain.

c. Fakta bahwa aktivitas permainan sederhana dapat menjadi kendaraan (vehicle) ke arah permainan yang kompleks, dapat dilihat dan terbukti saat mereka menjadi remaja.

\section{Jenis Permainan}

Menurut Mutiah (2010), Pada dasarnya, semua jenis permainan mempunyai tujuan yang sama yaitu bermain dengan menyenangkan, beberapa jenis permainan yaitu :

a. Permainan sensorimotor, yaitu perilaku yang diperlihatkan bayi untuk memperoleh kenikmatan dari melatih perkembangan skema sensorimotor.

b. Permainan praktis, yaitu melibatkan pengulangan perilaku ketika keterampilan baru sedang dipelajari.

c. Permainan pura-pura (simbolis), yaitu terjadi ketika anak menstransformsikan lingkungan fisik ke dalam suatu simbol

d. Permainan sosial, yaitu permainan yang melibatkan interaksi sosial dengan teman sebaya

e. Permainan fungsional, yaitu permainan pertama yang dilakukan pada awal masa kanak-kanak di mana anak mengulang -ulang kegiatan sederhana dan menemukan kesenangan dalam bermain dengan lingkungannya. Permainan ini bergunan untuk meningkatkan motorik anak

f. Permainan konstruktif, yaitu terjadi ketika anak-anak melibatkan diri dalam kreasi atau konstruksi suatu produk atau pemecahan masalah ciptaan sendiri.

g. Game, yaitu kegiatan-kegiatan yang dilakukan untuk memperoleh kenikmatan yang melibatkan aturan dan seringkali bersifat kompetisi.

Jenis permainan secara umum dapat digolongkan menjadi dua jenis yaitu permainan modern dan permainan tradisional. Fenomena permainan modern telah melahirkan suatu pemikiran pentingnya kembali memperkenalkan jenis permainan tradisional pada anak. Permainan modern lebih banyak berupa permainan statis. Anak lebih banyak bermain sendiri, kurang peduli pada lingkungan sehingga kemampuan sosial anak kurang dapat berkembang. Secara fisik hanya bagian anggota tubuh tertentu yang digunakan sehingga rentan memunculkan kelelahan. Secara emosi anak-anak akan cenderung sulit mengontrol emosinya karena cenderung ingin menang dan perasaan sangat kecewa bila mengalami kegagalan, gembira yang berlebihan ketika mengalami kemenangan. Bahkan sering dijumpai perasaan kecewa atau gembira yang berlebihan hingga anak melakukan tindakan destruktif dengan merusak barang yang ada di depannya.

\section{Permainan Tradisional}

Permainan tradisional merupakan kegiatan bermain yang dilakukan anakanak yang berasal dari budaya Indonesia. Permainan ini dimainkan oleh anak -anak secara bersamaan, berkelompok, bekerja sama dalam mencapai tujuan permainan dengan aturan yang telah ditetapkan. Tidak semua jenis permainan tradisional bisa dimainkan anak semua usia. 
Menurut Wardani seorang pemerhati budaya (2008) permainan tradisional memiliki karakteristik tersendiri yang dapat membedakan dari karakteristik yang lain. Pertama, permainan itu cenderung menggunakan alat atau fasilitas di lingkungan tanpa membelinya. karakteristik kedua, permainan tradisional dominan melibatkan pemain yang relatif banyak atau berorientasi komunal. Tidak mengherankan, kalau kita lihat, hampir setiap permainan rakyat begitu banyak anggotanya. Sebab, selain mendahulukan faktor kegembiraan bersama, permainan ini juga mempunyai maksud lebih pada pendalaman kemampuan interaksi antar pemain (potensi interpersonal). Seperti pada permainan jamuran, betengan, ular naga, dll.

\section{Pengembangan Kemampuan Sosial Anak}

Anak dilahirkan belum bersifat sosial, dalam arti belum memiliki kemampuan bergaul dengan orang lain. Untuk kematangan sosial, anak belajar tentang cara menyesuaikan diri dengan orang lain. Dalam kajian anak usia dini kemampuan sosial merujuk pada bagaimana anak-anak bergaul dengan teman sebaya.

Dalam yusuf (200:122) Perkembangan sosial anak sangat dipengaruhi oleh proses perlakuan atau bimbingan orang tua terhadap anak dalam mengenalkan berbagai aspek kehidupan sosial, atau norma-norma kehidupan bermasyarakat. Proses pembimbingan ini disebut sosialisasi. Suean Robinson Ambron dalam yusuf (2010: 123) mengartikan sosialisasi sebagai proses belajar yang membimbing anak ke arah perkembangan kepribadian sosial sehingga dapat menjadi anggota masyarakat yang bertanggung jawab dan efektif.

Parten dalam Janice W Beaty (2013: 134) menentukan enam kategori perilaku yang menjadi dasar menentukan tingkat kemampuan sosial anak -anak di beberapa bidang kajian, meliputi ;

a. Perilaku berdiam diri ; anak tidak terlihat dalam permainan sekitar dia, dia tetap di satu tempat, mengikuti guru, atau berkeliling

b. Perilaku penonton; anak menghabiskan banyak waktu yang dilakukan anak lain bahkan mungkin bicara dengan mereka, tetapi tidak bergabung dan berinteraksi secara fisik

c. Permainan sendiri; anak terlibat dalam kegiatan bermain tetapi bermain sendiri tidak dengan anak lain atau mainan mereka

d. Kegiatan paralel; anak bermain sendirian tetapi ia bermain di sebelah anak-anak lain dan sering kali menggunakan mainan atau material mereka

e. Permainan asosiatif; anak bermain dengan anak -anak lain menggunakan material yang sama dan bahkan berbicara dengan mereka, tetapi ia bertindak sekehendaknya dan tidak mau ikut aturan kelompok

f. Permainan kooperatif; anak bermain dalam kelompok yang ditata melakukan hal tertentu, dan yang anggotanya menjalankan peran berbeda

Melalui pergaulan sosial dengan teman sebaya,orang tua, anggota keluarga, orang dewasa anak mulai mengembangkan bentuk tingkah laku sosial, yaitu :

a. Pembangkangan (Negativistisme)

Tingkah laku melawan sebagai reaksi terhadap penerapan disiplin atau tuntutan orang tua atau lingkungan yang tidak sesuai dengan kehendak anak. Bentuk 
perlawan secara fisik kemudian secara verbal setelah usia enam tahun. Tingkah laku ini wajar, karena secara naluriah anak mempunyai dorongan untuk berkembang dari dependent (tergantung) menjadi independent (mandiri)

b. Agresi (aggression) perilaku menyerang baik secara fisik (nonverbal) maupun kata-kata (verbal). Agresi merupakan salah satu bentuk reaksi terhadap frustasi (rasa kecewa karena tidak terpenuhi keinginannya). Wujud agresi ini perilaku menyerang seperti memukul, mencubit, menendang, menggigit, marah-marah, mencaci maki.

c. Berselisih (quarreling),seorang anak merasa tersinggung atau terganggu oleh sikap dan perilaku anak lain, seperti direbut mainannya

d. Menggoda (teasing) bentuk lain dari agresi, merupakan serangan mental terhadap orang lain dalam bentuk verbal (kata ejekan atau cemooh) sehingga menimbulkan reaski marah pada orang lain

e. Persaingan (revarly) keinginan untuk melebihi orang lain dan selalu di dorong (distimulais) oleh orang lain. Sikap persaingan terlihat mulai usia empat tahun untuk prestise dan enam tahun semangat bersaing berkembang lebih baik

f. Kerjsama (cooperation) sikap bekerjasama dalam kelompok mulai tampak pada usia tiga atau empat tahun akhir, ini berkembang baik pada usia enam tahun

g. Tingkah laku berkuasa (ascendant behavior) perilaku menguasai situasi sosial, mendominasi , bersikap "bossiness". Wujud perilaku ini, menyuruh, meminta, mengancam, memaksa orang lain untuk memenuhi kebutuhannya

h. Mementingkan diri sendiri (selfisgness) perilaku egosentris dalam memenuhi interest / keinginannya, apabila ditolak ia protes dengan menangis, menjerit atau marah-marah

i. Simpati (Sympathy) sikap emosional yang mendorong individu untuk menaruh perhatian terhadap orang lain mau mendekati atau bekerja sama dengannya. Seiring bertambah usia maka sikap selfish anak akan berakhir dan mulai mengembangkan sikap sosialnya

Beaty (2013: 133) menyampaikan pemelajaran sosial yang penting bagai anak usia dini adalah sebagai berikut:

a. Melakukan kontak dan bermain dengan anak -anak lain

b. Berinteraksi dengan teman sebaya, untuk memberi dan menerima

c. Bergaul dengan teman sebaya untuk berinteraksi dengan harmonis

d. Memandang hal-hal dari sudut pandang anak lain

e. Mengenali giliran, menunggu giliran

f. Berbagi dengan anak-anak lain

g. Menunjukkan penghargaan pada anak-anak lain

h. Menyelesaikan konflik antarpersonal

Sejalan dengan pendapat Hurlock (1994: 159) pola permainan yang mendukung perkembangan sosial anak adalah pola permainan yang bernuansa sosial, yaitu pola permainan yang melibatkan interaksi dengan teman sebaya. Saat melakukan permainan tradisional anak berkumpul dan diajak untuk mengenal teman sebayanya. Dan menurut Santrock (2003) partisipasi sosial anak dalam suatu kelompok akan memenuhi kebutuhan atas hubungan dekat dan kebersamaan. 
Stone (1995) dan peneliti lain menyatakan bahwa bermain dengan anak lain memberi anak usia dini kesempatan terbaik untuk mempelajari kemampuan sosial. Permainan merupakan alat utama bagi pengembangan sosial anak-anak. permainann mendorong interaksi sosial. Anak-anak belajar bagaimana berunding, menyelesaikan konfik, menyelesaikan masalah, saling bergaul, mengambil giliran, bersabar, bekerjasama, dan berbagi. Permainan juga membentuk anak-anak memahami konsep keadilan dan persaingan.

\section{PENUTUP}

Nilai yang terkandung dalam permainan tradisional banyak mengangkat nilai luhur yang berada di Indonesia. Permainan tradisional memiliki aturan permainan yang sederhana ataupun yang disederhanakan. Kemampuan sosial anak akan kita dapati sebagai wujud internalisasi nilai budaya lokal dalam bentuk kerja sama, kesetiakawanan, dan gotong-royong di berbagai bidang kehidupan. Interaksi pada anak ketika sedang bermain memunculkan akibat yang menjadi stimulasi bagi berkembangnya kemampuan sosialnya. Mereka akan belajar untuk menghargai dan menyelesaikan konflik antar teman sebaya, dan mereka juga memiliki pengalaman merasakan keberhasilan dan kegagalan.

Tidak menjadi individu yang egosentris, yang hanya mementingkan diri sendiri, memiliki empati dengan orang lain, mengendalikan emosi untuk mengendalikan perilaku agresi dengan media permainan tradisional yang berasal dari budaya lokal. Kelebihan permainan tradisional bahwa permainan ini mampu mengembangkan keterampilan sosial anak, pada permainan yang bersifat kompetisi memberikan kesempatan pada anak untuk belajar bersaing dengan sehat dan mampu mengembangkan social skill, motoric skill, dan emotional skill. Keterlibatan anak dalam suatu kelompok sosial formal maupun informal akan membantu anak melatih kemampuan dalam menjalin hubungan yang hangat. Partisipasi sosial secara informal pada dapat dilakukan dengan melibatkan anak dalam kegiatan bermain dalam permainan tradisional

\section{DAFTAR PUSTAKA}

Beaty Jenice J, 2013. Obsevasi Pada Anak Usia Dini (terjemahan). Cetakan ketujuh: Pearson Education INC.

Cohen, David. 1993. The Development of Play. 2nd Edition. Tokyo : Routledge.

Hurlock, E. B. 1997. Psikologi Perkembangan. Edisi kelima.Jakarta :Erlangga.

Mutiah Diana, 2012. Psikologi Bermain Anak Usia Dini. Jakarta: Prenada media group.

Semiawan, C. R. 2003. Pengembangan Rambu-rambu Belajar Sambil Bermain pada Pendidikan Anak Usia Dini. Buletin PADU. Vol. 2, No. 1, April 2003. Jakarta: Direktorat Pendidikan Anak Usia Dini.

Tilaar,H.A.R.2002. Perubahan Sosial dan Pendidikan: Pengantar Pedagogik Transformatif untuk Indonesia. Jakarta: Grasindo.

Yusuf, Syamsu,LN, 2010. Psikologi Perkembangan Anak dan Remaja. Bandung: PT Rosdakarya. 